\title{
Linking rock fabric to fibrous mineralisation: a basic tool for the asbestos hazard
}

\author{
G. Vignaroli ${ }^{1}$, F. Rossetti ${ }^{1}$, G. Belardi ${ }^{2}$, and A. Billi ${ }^{2}$ \\ ${ }^{1}$ Dipartimento di Scienze Geologiche, Università Roma Tre, Largo S.L. Murialdo 1, 00146 Rome, Italy \\ ${ }^{2}$ Istituto di Geologia Ambientale e Geoingegneria, CNR, Area della Ricerca di Roma 1, Via Salaria Km 29, 300-00015, \\ Monterotondo Stazione, Rome, Italy
}

Received: 17 November 2010 - Revised: 3 March 2011 - Accepted: 6 March 2011 - Published: 9 May 2011

\begin{abstract}
In recent years, many studies have addressed the effect on human health caused by asbestos exposures. As asbestos is a group of fibrous minerals that mainly occurs in mafic and ultramafic rocks (ophiolitic sequences), a close relationship between asbestos occurrence and the geological history of host rocks should be expected. By reviewing the existing literature and presenting characteristic examples, it is proposed a direct correspondence exists between the presence of fibrous minerals in ophiolites and the rock fabric systematics due to the combined activity of deformation, metamorphism/metasomatism, and rock/fluid interaction. Understanding the geological factors that may be at the origin of the nucleation/growth of fibrous minerals constitutes a necessary requirement for developing a methodological and analytical procedure to evaluate asbestos hazard $\left(A_{\mathrm{H}}\right)$ in the natural prototype (ophiolitic rocks). A parameterisation of the $A_{\mathrm{H}}$ in function of the main geological processes that produce the rock fabric systematics in different tectonic/geodynamic settings is discussed. A geological multidisciplinary approach (based on geological-structural field evidence combined with textural, mineralogical, petrological, and geochemical investigations) is proposed as the prerequisite for the evaluation of $A_{\mathrm{H}}$ in natural environments. This approach, in particular, can provide a robust basis to formulate a procedural protocol finalised to the mitigation of asbestos effects in environments where these effects are still a real threat.
\end{abstract}

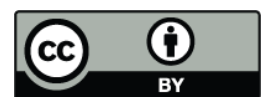

Correspondence to: G. Vignaroli (vignarol@geo.uniroma3.it)

\section{Introduction}

Asbestos is the commercial term commonly used for six silicate minerals (World Health Organization, 1986; Gunter et al., 2007; Gunter, 2010). Due to its useful manufacturing properties, the use and commercialization of asbestos started already in archaeological ages. Since the advent of modern industry in the 19th century, asbestos has been mined and used all around the world (e.g. Ross and Nolan, 2003, and Kazan-Allen, 2005, for a review), while its negative effects on human health were increasingly being defined (e.g. asbestosis, mesothelioma, and lung cancer; Doll, 1955; Mossman et al., 1990; Hughes and Weill, 1991; Wagner, 1991; Rey et al., 1994; Cattaneo et al., 2006). At present, asbestos is listed as a Group I human carcinogen matter by the international world health authorities (IARC, 1987).

Although new fibrous minerals have been and are being discovered (e.g. Compagnoni et al., 1983, 1985; Gianfagna et al., 2003; Meeker et al., 2003; Belluso et al., 2006; Sullivan, 2007), in several countries asbestos is usually classified into two main mineral groups for legislative purposes: serpentine (chrysotile) and amphibole (amosite, crocidolite, anthophyllite, tremolite, and actinolite). Despite the fact that regulatory agencies attempt to control the environmental impact of these minerals (e.g. Gibbons, 1998; Ross and Nolan, 2003; KazanAllen, 2005; de Grisogono and Mottana, 2009; Strohmeier et al., 2010) and that information on the asbestos hazard has multiplied in the last years (e.g. Gunter et al., 2007), asbestos is still an important threat to human health, particularly in urban settings where excavation, milling, and transportation of asbestos-bearing rocks during engineering activities (such as quarrying, tunnelling, and railways construction) potentially induce environmental risks for both workers and residents (e.g. Rohl et al., 1977; Schreier, 1989; Ross and Nolan, 2003; de Grisogono and Mottana, 2009). 


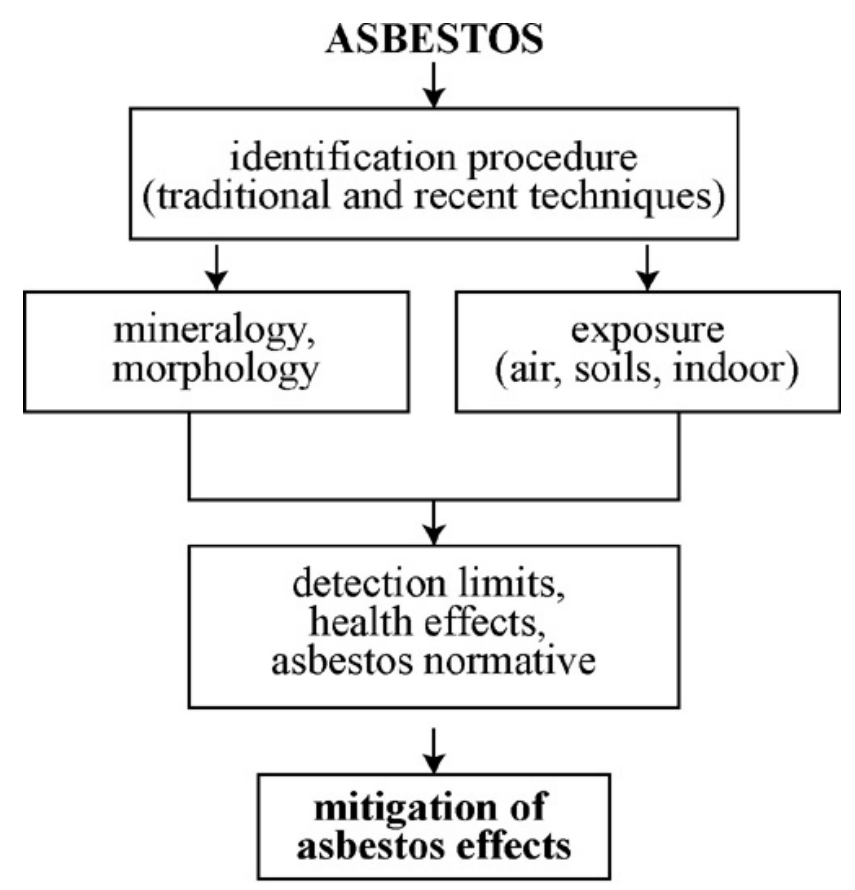

Fig. 1. Flowchart correlating the asbestos hazard to mitigation effects in natural environments.

Research on asbestos hazard has hitherto been based mainly on measurements of concentrations of dispersed fibres in air (e.g. Sebastien et al., 1982; Lange et al., 1996; Zakrzewska et al., 2008), soils/water (e.g. Burilkov and Michailova, 1970; Metintas et al., 2002; Emmanouil et al., 2009), and indoors (e.g. Hardy et al., 1992). Results from these measurements have been mainly used to align the asbestos concentrations to the incidence of diseases, or to support national laws regulating the asbestos content in natural environments. It follows that policy makers and emergency responders have so far focussed more on the symptoms of the problem (mitigation effects) rather than on the cause (Fig. 1). On the other hand, only few studies have addressed the potential risks posed to health by asbestos minerals occurring in their natural settings (e.g. Gabrielse, 1960; Gibbons, 2000; Ross and Nolan, 2003; Van Gosen, 2007; Hendrickx, 2009; Thompson et al., 2011). As asbestos is a mineral typical of mafic and ultramafic rock sequences (i.e. ophiolites), the cause for asbestos concentrations and hazard most commonly resides in ophiolitic rocks. However, only some of these rocks bear minerals and associated soils hazardous to human health. Understanding what geological history may lead to the formation of hazardous minerals in ophiolites is therefore fundamental to mitigate the asbestos hazard at its origin.

The aim of this paper is to investigate the range of the geological processes involved in the development of the asbestos-bearing ophiolitic rocks in order to promote some operative indications for procedures to be adopted before starting engineering works involving ophiolitic rocks both in urban settings and in natural environments.

\section{Asbestos in ophiolitic rocks: when and why?}

Deposits of asbestos occur world-wide and as such asbestos there have been concerns for non-occupational exposure (e.g. Phillips, 1927; Schreier, 1989; Karkanas, 1995; Ross and Nolan, 2003; Van Gosen, 2007; Hendrickx, 2009). Although large asbestos deposits have been documented in metavolcanics (Gianfagna et al., 2003) and metamorphosed iron formations (Van Gosen, 2007), loci of intensive asbestos mines (both active and inactive) correspond to exposures of ophiolitic rock sequences.

A complete ophiolite suite consists of basal peridotites showing different olivine-clinopyroxene-orthopyroxene associations (harzburgite, lherzolite, pyroxenite, dunite, etc.) and a main granular-to-porphyroclastic microtexture; overlaying intrusive gabbros (often exhibiting cumulus textures) and dykes; effusive complex mostly comprising pillow basalts; tectonosedimentary breccias (ophicalcites); and pre-to-syn-rift sedimentary cover (e.g. Müntener and Piccardo, 2003). Within this wide spectrum of ophiolitic rock types, chrysotile deposits are concentrated in the ultramafic rocks (peridotites, serpentinized peridotites, serpentinites), whereas amphibole asbestos may be present in gabbros, serpentinoschists, and various metasedimentary rocks.

What follows is a review of the geological aspects that pertain to asbestos formation, starting from the geological processes associated with the genesis and exposure of ophiolites in continental areas, where they interact with the human population.

\subsection{The geodynamic settings}

Ophiolites are remnants of paleo-oceanic lithosphere and their present-day exposures are a direct manifestation of the Wilson cycle of plate tectonics, from oceanic construction at divergent plate boundaries to oceanic consumption at convergent plate margins during orogenesis and crustal growth (e.g. Dilek and Robinson, 2003, and references therein). Creation of ophiolites dominantly occur at oceanic spreading centres in consequence of rifting processes during fragmentation of either continental or oceanic lithosphere (Coleman, 1977; Moores, 1982), although increasing importance has been attributed to ophiolites formed in supra-subduction zone environments (Dilek and Robinson, 2003). Theoretical models concerning exposure of mafic and ultramafic suites at the sea-floor in spreading centres include both simple- (e.g. McKenzie and Bickle, 1988) and pure-shear (e.g. Whitmarsh et al., 2001) criteria of lithospheric extension. In the first case (Fig. 2a), ophiolite formation is linked to the activity of lowangle normal fault systems that enhance hydrothermal alteration and chemical contamination due to pervasive seawater 


\section{a) Ophiolite formation and hydrothermal metamorphism (serpentinization)}

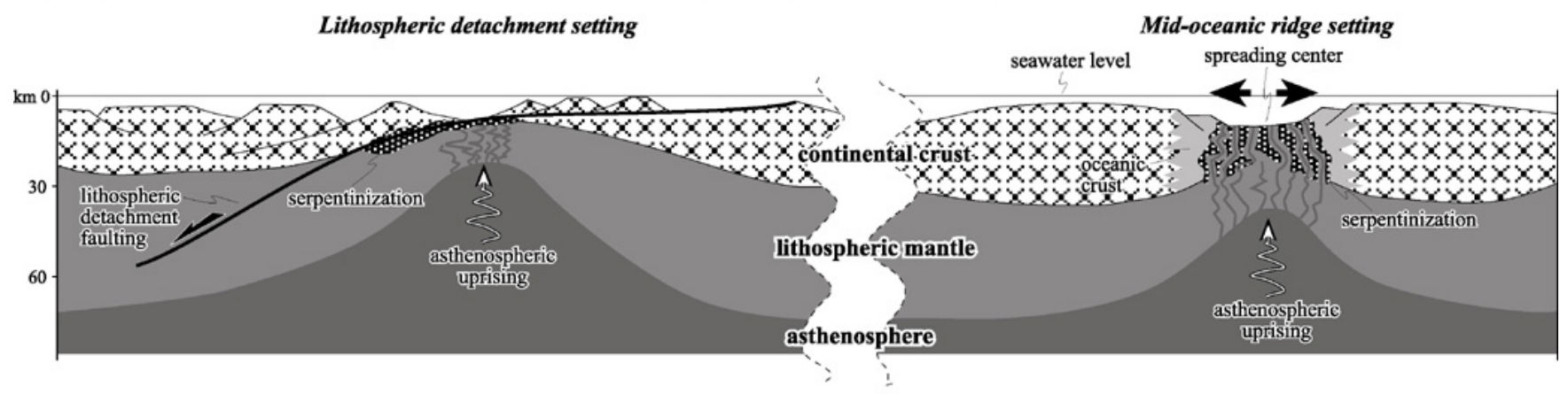

b) Ophiolite emplacement in subduction-exhumation cycle

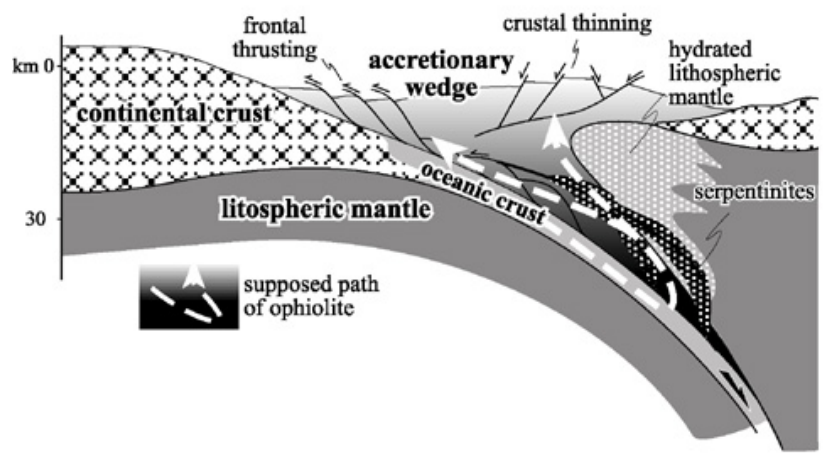

c) Ophiolite emplacement during obduction

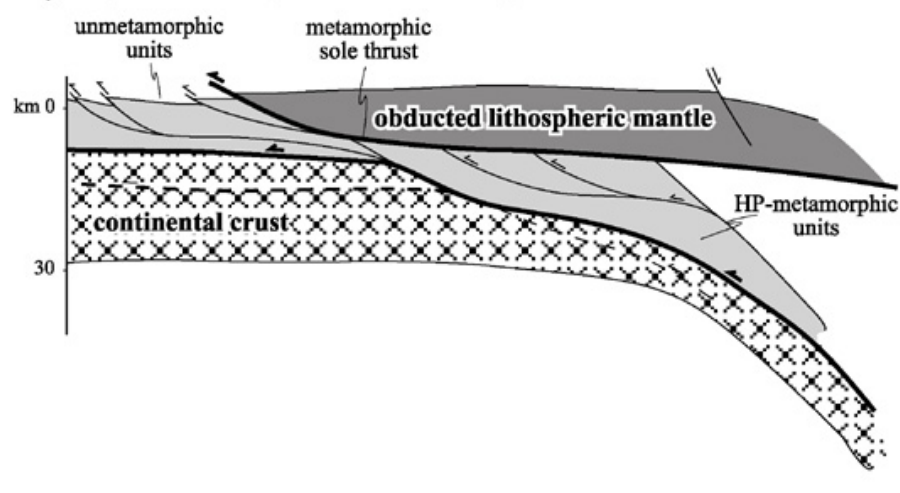

Fig. 2. Schematic scenarios of tectonic settings for ophiolites. (a) Mantle exhumation and ophiolite formation during two main crustal mechanisms: lithospheric detachment (e.g. McKenzie and Bickle, 1988, redrawn and modified) and coaxial stretching at the mid-oceanic ridge (e.g. Whitmarsh et al., 2001, redrawn and modified). (b) Subduction-exhumation setting illustrating possible tectono-metamorphic events experienced by ophiolites (after Agard et al., 2009, redrawn and modified). (c) Ophiolite obduction along a regional-scale metamorphic sole thrust (after Searle et al., 2003, redrawn and modified).

penetration during uprising (e.g. Giguère et al., 2003; Mével, 2003). In the second case, divergent plate motion at the oceanic ridge produces dilatation and cracking in the thin oceanic floor with consequent permeation of mantle rocks at surficial conditions.

Apart from processes associated with sea floor formation, the majority of the present-day exposures of ophiolitic sequences coincides with the axial (inner) regions of both active and ancient mountain belts (Dewey and Bird, 1970; Coleman, 1971). The classical scenario of mountain belt considers subduction of an oceanic plate followed by continental collision and suturing at the termination of the classical Wilson cycle (Dewey and Bird, 1970; Cawood et al., 2009, and references therein). In this context, orogenic wedge formation occurs in the supra-subduction zone due to the continuous flux, burial, and exhumation of the material detached from the subduction plate (e.g., Platt, 1986, 1993; Cloos and Shreve, 1988; Jolivet et al., 2003; Agard et al., 2009; Guillot et al., 2009). Meanwhile, ophiolites undergo a series of tectono-metamorphic events within the subduction channel, progressively equilibrated under highpressure/low-temperature ( $\mathrm{H} P / \mathrm{L} T)$ metamorphic conditions (e.g. Peacock, 1996; Hacker et al., 2003; Guillot et al., 2009) with concomitant metasomatism induced by the circulating fluid phase (e.g. Scambelluri and Philippot, 2001; Schmidt and Poli, 2003; Bebout, 2007) (Fig. 2b). Circulation within the subduction channel results in the development of polyphase deformation fabrics and metamorphic mineral assemblages that modify the original texture, mineralogy, and rheology of pristine ophiolites (Scambelluri et al., 1995; Hermann et al., 2000; Andreani et al., 2005). Orogenic processes may also involve oceanic obduction, which constitutes the tectonic juxtaposition of the oceanic lithosphere onto continental margins (e.g. Coleman, 1977). As in the case of the Semail ophiolites in Oman (e.g. Coleman, 1981; Searle et al., 2003, and references therein), the obducted ophiolites constitute an almost preserved oceanic lithospheric section, overthrusted along a regional-scale sole thrust (Fig. 2c). The lack of penetrative subduction-zone metamorphism within the Semail ophiolite mass is one of the most important evidence 


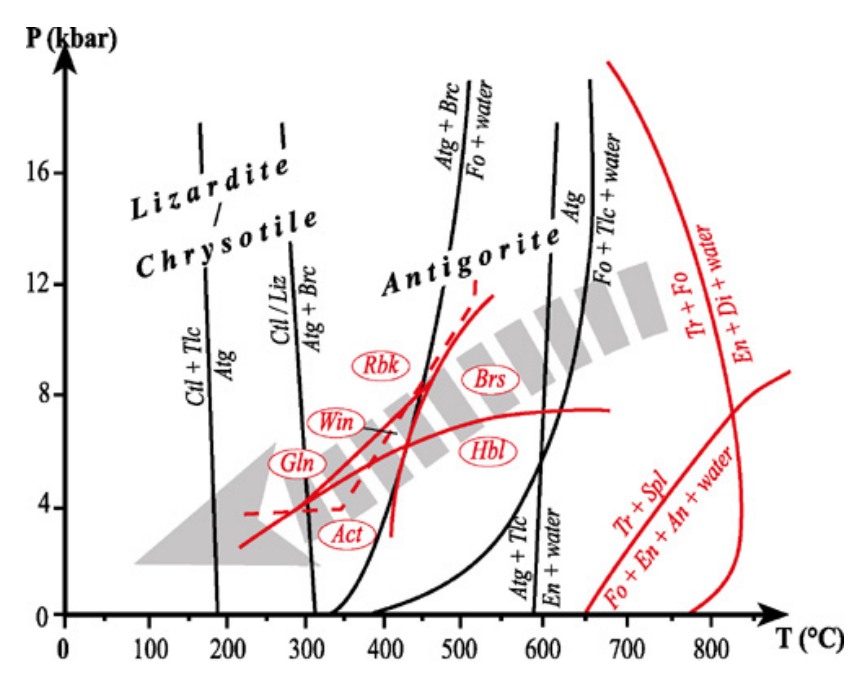

Fig. 3. Qualitative $P-T$ conditions of stability for serpentine and amphibole minerals. Reactions for serpentines are taken from Wunder et al. (2001); Bucher and Frey (2002); and Evans (2004). Amphiboles fields are taken from Otsuki and Banno (1990); Parra et al. (2000); and Bucher and Frey (2002). Mineral abbreviations: Act: actinolite; An: anorthite; Atg: antigorite; Brc: brucite; Brs: barroisite; Ctl: chrysotile; Di: diopside; En: enstatite; Fo: forsterite; Gln: glaucophane; Hbl: hornblende; Liz: lizardite; Rbk: riebeckite; Spl: spinel; Tlc: talc; Tr: tremolite; Win: winchite.

of the obduction process, with deformation, metamorphism, and fluid-rock mainly localized within the metamorphic sole thrust (e.g. Gray and Gregory, 2003).

Consequently, despite their original stratigraphic sequence, ophiolitic suites usually show complexities in terms of superimposed structures and mineralogical assemblages (i.e. the rock fabric), an inheritance of the tectonometamorphic history from sea floor formation and/or orogenic wedge construction (e.g. Hermann and Müntener, 1996; Boschi et al., 2006; Nuriel et al., 2009). Within this wide range of geological processes, shear deformation and fluid-rock interaction enhance rock alteration and serpentinization, including fibrous minerals, under particular conditions of temperature and pressure (e.g. Trommsdorff and Evans, 1974; Evans, 2004).

\subsection{The $P$-T metamorphic conditions}

In metamorphic petrology, the crystallization of a specific mineral assemblage, including also fibrous minerals potentially hazardous to human health, reflects pressure and temperature $(P-T)$ equilibrium conditions attained during the metamorphic evolution. Fibrous mineralisation can therefore be seen as snapshots of the progressive crystallization process occurring in the rock mass, in consequence of the experienced tectono/metamorphic evolution.

Figure 3 summarizes the $P-T$ conditions for stability of serpentine and some amphibole minerals. Serpentine miner- als equilibrate in a wide field of both $T$ and $P$. Antigorite is stable from 200 to $660^{\circ} \mathrm{C}$, over low-grade to eclogitic conditions (e.g. Bucher and Frey, 2002; Evans, 2004). Antigorite mostly forms by destabilization of pristine peridotitic mineral assemblages by water activity-dependent reactions (e.g. Trommsdorff and Evans, 1974; Evans, 1977; Hermann et al., 2000; Bucher and Frey, 2002; Andreani et al., 2007), such as:

$$
\begin{aligned}
& \text { forsterite }+ \text { water }=\text { antigorite }+ \text { brucite } \\
& \text { enstatite }+ \text { water }=\text { antigorite }+ \text { talc } \\
& \text { forsterite }+ \text { talc }+ \text { water }=\text { antigorite }
\end{aligned}
$$

Chrysotile and lizardite are (meta)stable phases at temperatures lower than $300^{\circ} \mathrm{C}$ (Evans, 2004), following the reaction:

antigorite + brucite $=$ chrysotile $/$ lizardite.

Complete destabilization of antigorite in favour of chrysotile/lizardite occurs at $T<200^{\circ} \mathrm{C}$ with production of talc:

antigorite $=$ chrysotile $/$ lizardite + talc.

It is important to note that chrysotile does not crystallize directly from early peridotitic assemblages, but it develops from the destabilization of former antigorite.

The stability fields of amphiboles depend on the variation in chemical composition of sodic- and calcic-rich species (Evans, 1990; Dale et al., 2005). Nucleation of tremolite in peridotites can occur following the destabilization of olivine, orthopyroxene, and clinopyroxene in presence of aqueous fluid (Bucher and Frey, 2002):

forsterite + enstatite + anorthite + water $=$ tremolite $+\operatorname{spinel}(6)$

enstatite + diopside + water $=$ tremolite + forsterite.

Tremolite is stable from temperature lower than $800^{\circ} \mathrm{C}$, down to the greenschists facies field (i.e. $300-400^{\circ} \mathrm{C}$ ). Crystallization of actinolite and crocidolite (the asbestos variety of riebeckite) attains at $T<400^{\circ} \mathrm{C}$ over medium-to-high pressure conditions (Otsuki and Banno, 1990; Fig. 3).

From the above notions, it can be inferred that the nucleation of both serpentine and amphibole asbestos is expected in ophiolitic rocks that experienced cooling during decompression from high-grade metamorphic conditions, after destabilization of former minerals. This can be attained by following different metamorphic retrograde paths (i.e. towards surficial $P-T$ conditions) that can span from (i) a trajectory characterized by nearly isobaric cooling and, then, nearly isothermal decompression, to (ii) a trajectory with first nearly isothermal decompression and, then, nearly isobaric cooling. Such retrograde paths are representative of the exhumation processes attained by the metamorphic rocks during the orogenic cycle (e.g. Platt, 1993; Spear, 1993). 
Table 1. Summary of the deformation fabrics hosting fibres in ophiolites.

\begin{tabular}{|c|c|c|c|c|}
\hline Rheological regime & Structures & $\begin{array}{l}\text { Preferential site of fi- } \\
\text { bre formation }\end{array}$ & $\begin{array}{l}\text { Common meso- and } \\
\text { micro-scale features }\end{array}$ & $\begin{array}{l}\text { Considered refe- } \\
\text { rences }\end{array}$ \\
\hline \multirow{2}{*}{ Ductile } & Mylonitic shear zones & On the schistosity & $\begin{array}{l}\text { Schistosity, stretching } \\
\text { lineation }\end{array}$ & $\begin{array}{l}{[1],[2],[4],[5],} \\
{[6],[7],[8],[9],} \\
{[10],[12],[18],} \\
{[19]}\end{array}$ \\
\hline & Syn-metamorphic veins & Within vein walls & $\begin{array}{l}\text { Cross- and slip-fibre } \\
\text { veins }\end{array}$ & $\begin{array}{l}{[1],[2],[3],[7],} \\
{[8],[11],[13],} \\
{[14],[15],[16],} \\
{[20],[21]}\end{array}$ \\
\hline Semi-ductile/semi-brittle & Tensile/shear fractures & Within fracture walls & $\begin{array}{l}\text { Cross- and slip-fibre } \\
\text { fractures }\end{array}$ & $\begin{array}{l}{[3],[7],[8],[12],} \\
{[17],[19]}\end{array}$ \\
\hline \multirow{2}{*}{ Brittle } & Fault gouges & On the slip planes & $\begin{array}{l}\text { Slip kinematic indica- } \\
\text { tors }\end{array}$ & $\begin{array}{l}{[6],[7],[8],[12],} \\
{[17]}\end{array}$ \\
\hline & Fault surfaces & On the fault surface & $\begin{array}{l}\text { Slip kinematic indica- } \\
\text { tors }\end{array}$ & {$[6],[7]$} \\
\hline
\end{tabular}

[1] Trommsdorff and Evans (1974); [2] Evans (1977); [3] Wicks and Wittaker (1977); [4] Piccardo et al. (1988); [5] Scambelluri et al. (1991); [6] Hoogerduijn Strating and Vissers (1994); [7] Karkanas (1995); [8] Hermann et al. (2000); [9] Reinen (2000); [10] Li et al. (2004); [11] Bellot (2008); [12] Andreani et al. (2005); [13] Barker et al. (2006); [14] Auzende et al. (2006); [15] Compagnoni and Groppo (2006); [16] Groppo et al. (2006); [17] Hirose et al. (2006); [18] Hirauchi and Yamaguchi (2007); [19] Giacomini et al. (2010); [20] Groppo and Compagnoni (2007); [21] Phillips (1927).

\subsection{Rock fabric evolution}

Within orogenic belts, ophiolites define large, but usually discontinuous bodies confined by regional-scale tectonic contacts responsible for the tectonic juxtaposition onto basement rocks (gneiss, granites) (Fig. 4a). The fabric of deformed ophiolites corresponds to different size deformation structures (from centimetre- to regional-scale), usually dissecting the original stratigraphic setting and obscuring the pristine rock fabric (Fig. 4b, c). Fibrous texture occurrence is documented both in shear deformation structures such as mylonites and fault gouges; and in non-shear deformation structures such veins, developed in both ductile and brittle regimes (Table 1). Processes involved in formation of shear structures include reduction in grain-size, progressive development of pervasive foliation, and crystallization of deformation-related minerals in presence or absence of aqueous fluids (Trommsdorff and Evans, 1974; Scambelluri et al., 1991). Schistose serpentinites (Fig. 5a, b) define the common example of large amount of localised ductile shearing, as they accommodate fault slip surfaces by the combined effect of kinematics and crystallization (e.g. Norrell et al., 1989; Hoogerduijn Strating and Vissers, 1994; Vissers et al., 1995; Karkanas, 1995; Hermann et al., 2000; Andreani et al., 2005). Within schistose serpentinites, syn-kinematic fibrous minerals are disposed parallel among them and define a structural preferential orientation (Fig. 5c). Mechanisms promoting fibrous mineralisation during ductile shearing are mainly classified into (i) ongoing (re)crystallization of fibres during syn-kinematic schistosity (Andreani et al., 2005; Hirauchi and Yamaguchi, 2007), and (ii) re-orientation of preexisting fibres (Reinen, 2000). At more brittle rheological conditions, shear structures (fault gouges, fault planes) localize the deformation in the rock mass immediately at the boundary of the main slip surface. Fault gouges produce a cataclastic tectonic melange (Fig. 5d) accommodating several meters of displacement by pervasive fragmentation of the host rock (e.g. Hoogerduijn Strating and Vissers, 1994; Hirauchi and Yamaguchi, 2007). External fluids permeate along the slip planes favouring the mineralisation of fibres. Interconnection between different fault systems can be provided by minor brittle structures (secondary faults, fracturing network) that also define a hydraulic pathway for fluid migration within the rock volume. Along fault surfaces, fibres tend to occur along the slip planes (Fig. 5e) parallel to the slip direction. Within these semi-brittle deformation conditions, back-scattered electron (BSE) images reveal that single fibres may be fragmented (Fig. 5f). Micro-cleavage occurs parallel (and along) the fibre length (i.e. the length-wise separation), and new formed fibres tend to arrange themselves parallel to the cleavages. It should be noted that, statistically, new formed fibres are shorter and thinner with respect to the pristine mineral from which they originated. Although the fibres maintain a similar aspect ratio (i.e. the length divided by its width), their negative effects on human health may increase as the particles reach a respirable size (e.g. Gunter et al., 2007). 

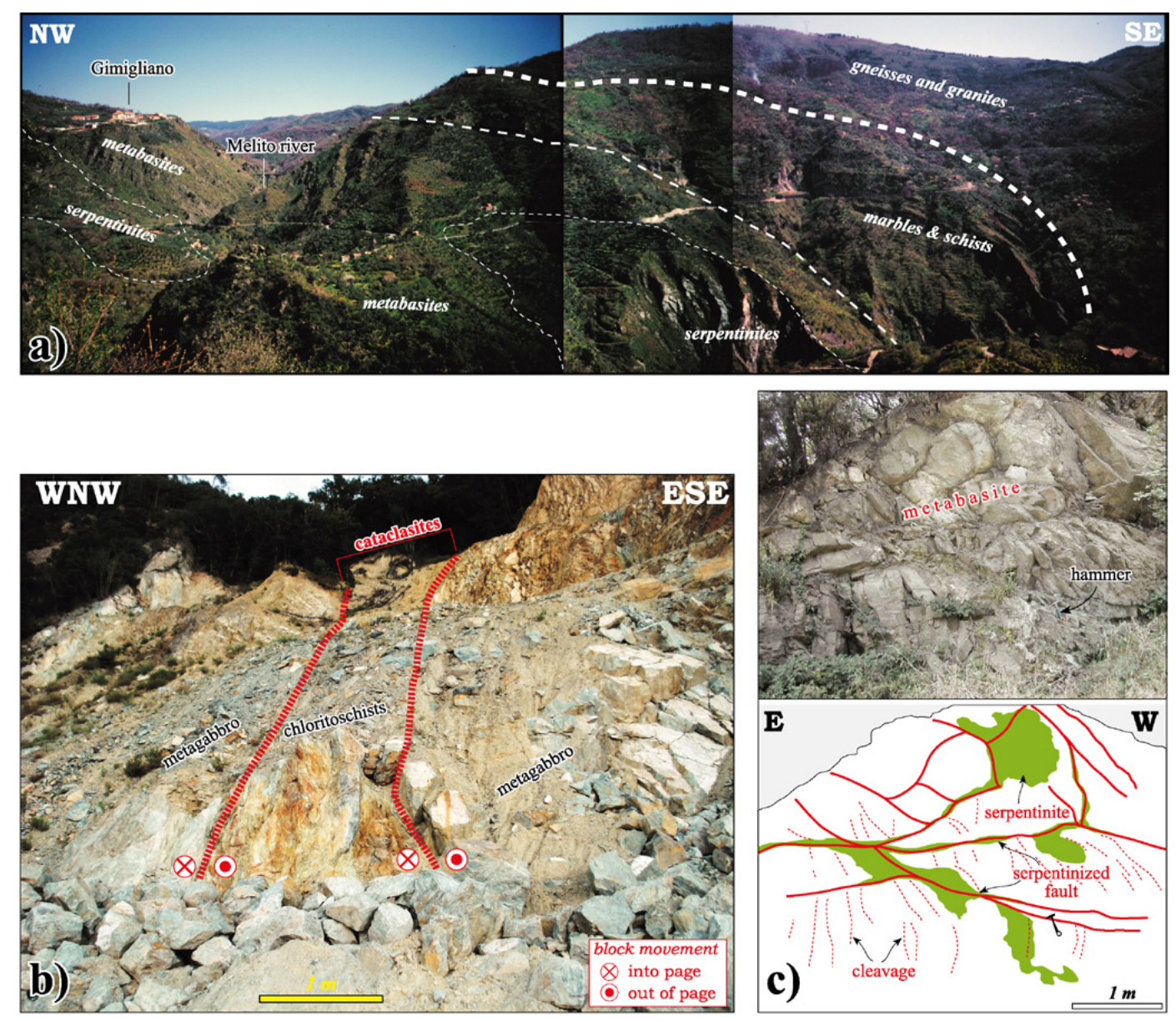

Fig. 4. (a) View of a tectonic window in Calabria region (southern Italy), where ophiolitic sequences are bounded from overlying continental basement units by tectonic contacts (after Rossetti et al., 2001); (b) metagabbros with sheared zone of foliated chloritoschists (Ligurian Alps, Italy); (c) picture and line-drawing of massive metabasite with pervasive serpentinized fault systems (Ligurian Alps, Italy).

Non-shear structures (e.g. syn-metamorphic veins, tensile fractures; Passchier and Trouw, 2005) can be thought as dilatation sites in rocks where fibrous mineral form in concomitance of fluid circulation (e.g. Wicks and Wittaker, 1977; Karkanas, 1995; Hermann et al., 2000; Auzende et al., 2006; Compagnoni and Groppo, 2006). Syn-tectonic veins are sites of mineral crystallization characterized by confined mass transfer processes (Cox and Etheridge, 1989; Barker et al., 2006). Fibrous serpentine texture in vein can occur in response to progressive, incremental crystallographic orientation during mineral formation (Andreani et al., 2004). Slipfibres structures present fibrous minerals disposed parallel with respect to the vein walls (Fig. 6a). In cross-fibres structures, fibres tend to be disposed roughly perpendicular to the boundaries of the vein (Fig. 6b). In both cases, fibres are confined within the vein body and their length and amount are directly proportional to the displacement rate (slip-fibre veins) and to the width of the vein (cross-fibre veins). Commonly, tensile fractures (fracture mode-1 of Atkinson, 1987) developed within massive mafic rocks display fibres arranged in flaws and dispersed on the fracture surfaces (Fig. 6c). In that case, fibres do not cover the entire fracture surface, but a patchy distribution is more common. At the microscale, fibres appear as confined within the fracture walls, showing textural equilibrium with the fracture-filled minerals (e.g. quartz or plagioclase) (Fig. 6d). Within this microstructure, fibre length (and abundance) depends on the fracture surface and aperture.

\subsection{Fluid-rock interaction}

Both ductile and brittle deformation patterns induce mechanical perturbation in the rock volume that corresponds to preferential pathways for fluid flow in rocks (secondary permeability creation and maintenance; Oliver, 1996, and references therein). Structurally-controlled fluid flow plays a major role in mineral reactions, mass transfer, and deformation in metamorphic rocks (Ferry et al., 1994). Metasomatism of ophiolitic rocks by contamination due to silica-rich fluids allows the destabilization of former mineral assemblages (e.g. 


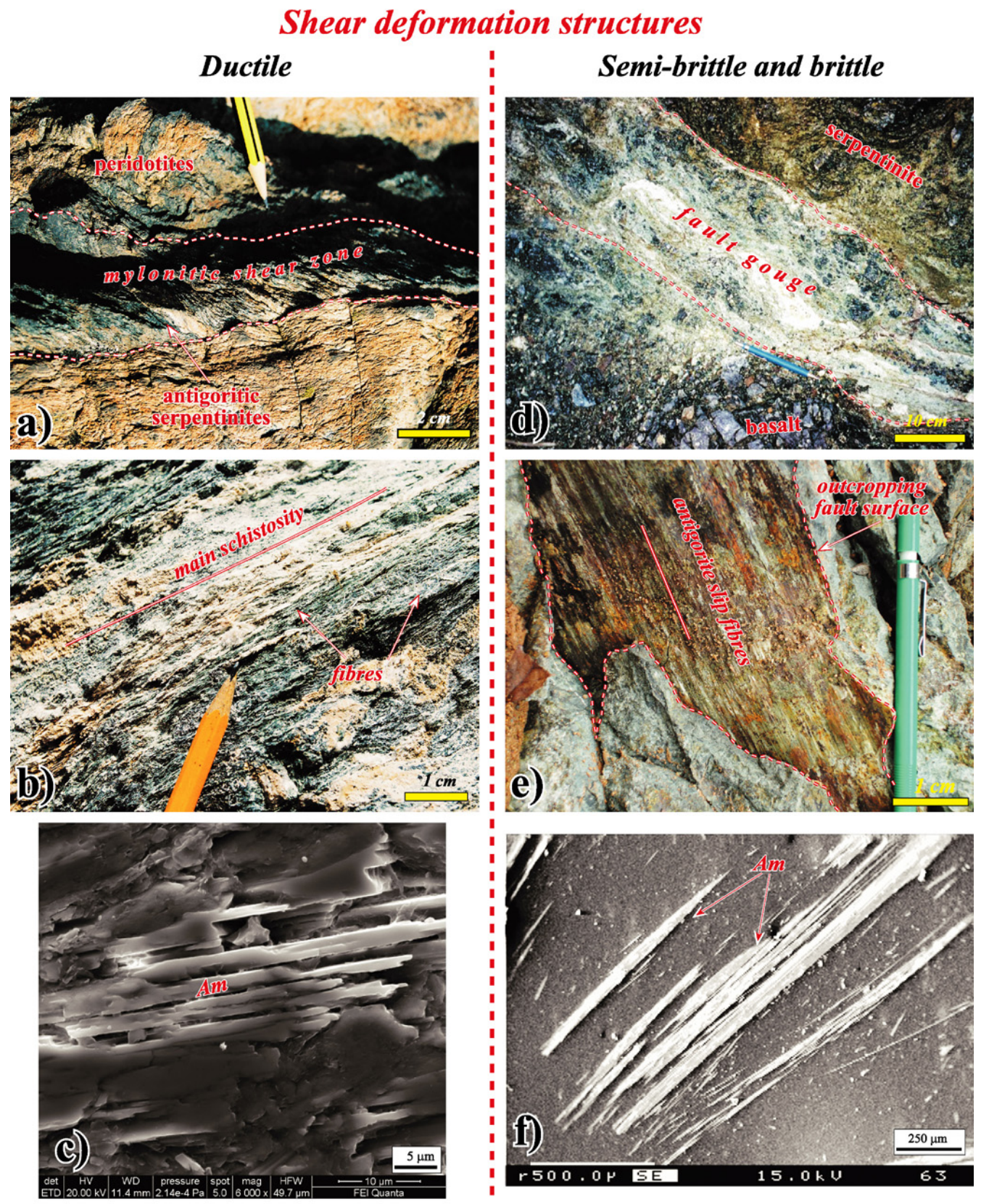

Fig. 5. Examples of ductile and brittle shearing in ophiolites. (a) Meso-scale ductile mylonitic shear zone with development of serpentinites in massive lherzolites; (b) meso-scale pervasive schistosity in serpentinites accomplished by occurrence of free asbestiform minerals (probably tremolite); (c) SEM image of strongly aligned amphibole in foliated microfabric; (d) decimetric-width fault gouges in serpentinites with fine-grained antigorite (the white horizons); (e) antigorite slip fibres developed on fault surface in metagabbros; (f) BSE images of fibrous amphiboles showing fracturing in parallel thinner fibres. Mineral abbreviation: Am: amphibole.

olivine, pyroxene) in favour to hydrated ones (e.g. serpentines and amphiboles) (e.g. Trommsdorff and Evans, 1974; Evans, 1977; Schmidt and Poli, 2003; Bebout, 2007; Bellot, 2008). The continuous feedback between dynamic recrystallization, strain localization, and fluid channelling implies deep changes into the structural permeability of the rock volume (e.g. Etheridge et al., 1984; Barnes et al., 2004).
In upper crustal conditions, fault-related fracture systems are the most important mechanism allowing infiltration of external fluids (e.g. Kerrich, 1986; Marquer and Burkhard, 1992). The extreme heterogeneity within the structural architecture of fault zones induces hydrodynamic partition within the massive protolith (e.g. Caine et al., 1996). Chemical disequilibrium between external fluid flow and wallrock has been 


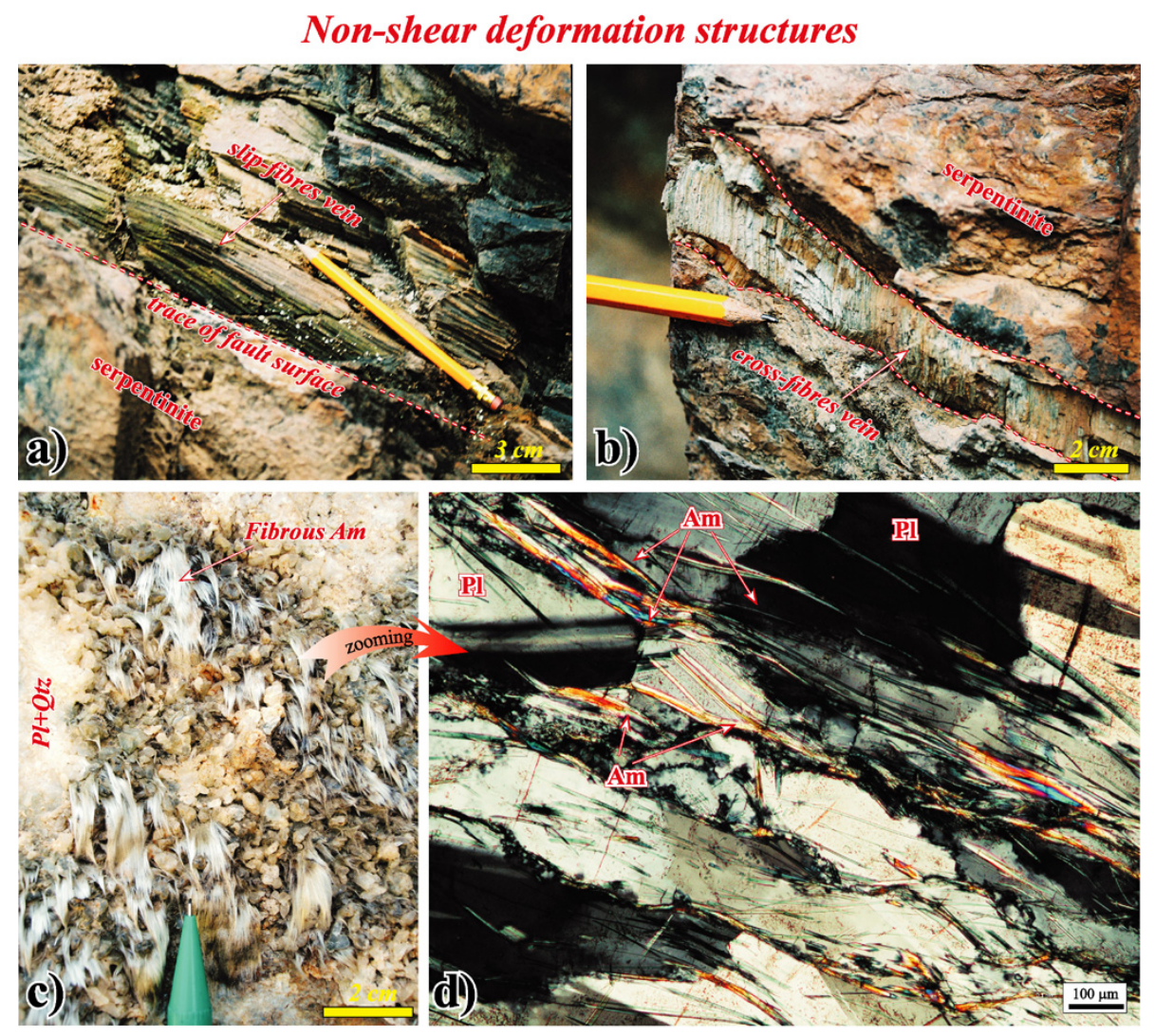

Fig. 6. Examples of non-shear deformation structures in ophiolites. (a) Antigorite slip-fibre and (b) antigorite cross-fibre veins in massive serpentinites; (c) tensile fracture in massive metagabbro with filling mineralisation composed by quartz, plagioclase, and fibrous amphiboles; (d) microphoto of thin section from fracture in (c), showing a plagioclase texture hosting fibrous amphibole crystals. Mineral abbreviations: Am: amphibole; Pl: plagioclase; Qtz: quartz.

described as responsible of development of secondary mineralisation in ophiolites (e.g. O'Hanley, 1991; Kyser et al., 1999), including fibrous ones (Karkanas, 1995). Within this "open system" fluid flow process (Oliver, 1996, and references therein), geochemical contamination acts through major fluid-hosted structures and is not pervasive within the undeformed wallrock volume.

\section{Discussion}

The asbestos hazard in ophiolites is intimately connected with the geological properties of the rock mass. The asbestos occurrence is not a casual aspect, but testifies of a series of geological factors that are diagnostics of the geological history of the host rocks.

A large literature documents the occurrence of both asbestos serpentines and asbestos amphiboles in different mafic and ultramafic lithologies, as well as in metasediments (e.g. Ross and Nolan, 2003; Compagnoni and Groppo, 2006; Van Gosen, 2007; Hendrickx, 2009; Giacomini et al., 2010). It is therefore inferred that the lithological heterogeneity of the ophiolitic rocks is not the main factor controlling the asbestos formation.

The following points should be taken into account:

- asbestos is not a primary constituent of the ophiolitic rock mass;

- asbestos is typically described in specific structural conditions of the rock mass;

- a narrow range of pressure and temperature conditions control the stability field of these minerals;

- chemical alteration of the host rock is often responsible for the formation of asbestiform minerals.

Through the above-reported comparison between previous works and our experience, we recognise a first-order correlation between asbestos formation (the asbestos hazard: $A_{\mathrm{H}}$ ) in ophiolites with (i) the metamorphic cooling/decompression history (cd), (ii) the interplay between ductile and brittle deformation structures and the derived secondary permeability (sp), (iii) the activity of polyphase deformation (pd), and 


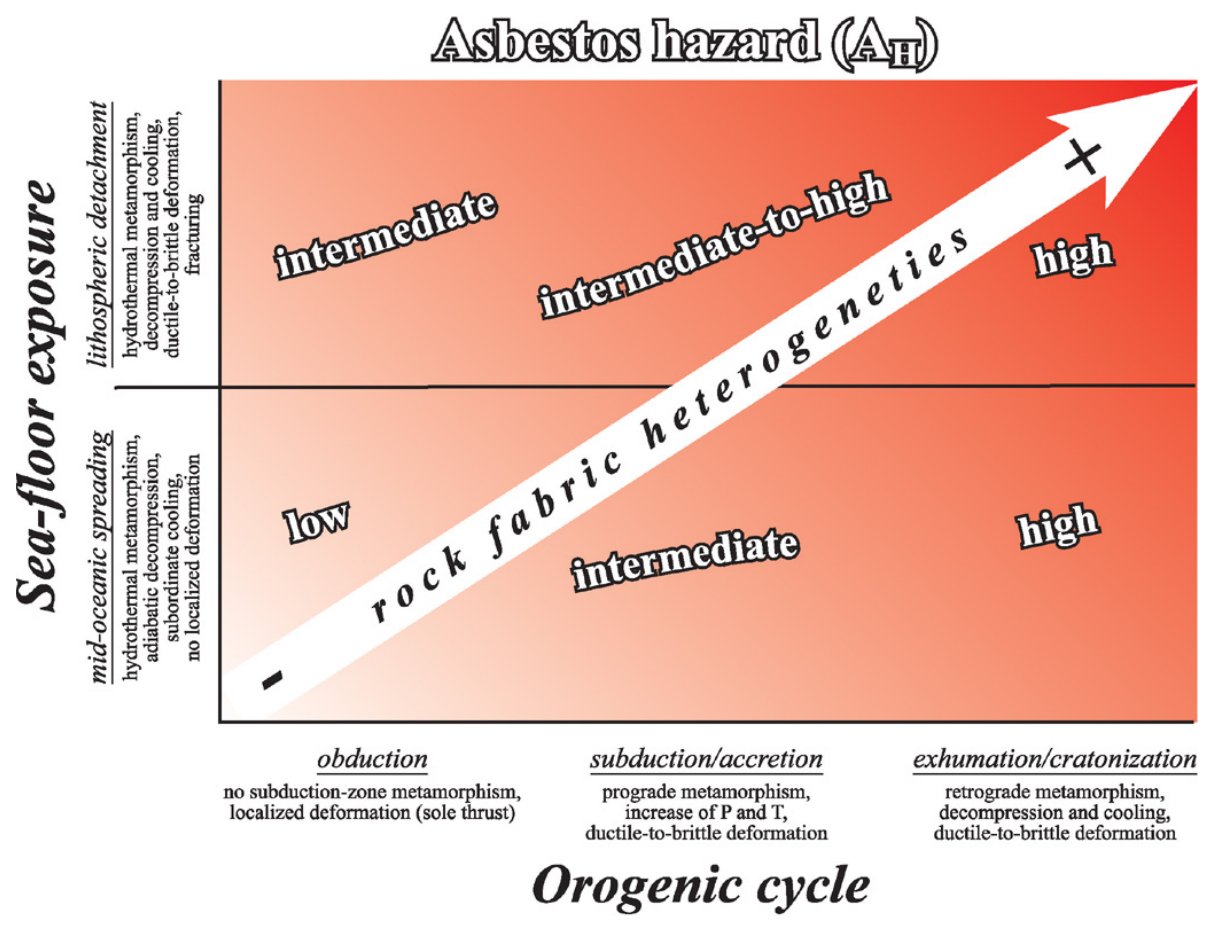

Fig. 7. Schematic diagram correlating the asbestos hazard in ophiolites $\left(A_{\mathrm{H}}\right)$ to the modality of sea-floor exposure and different orogenic stages. The $A_{\mathrm{H}}$ is expressed as a spectrum of possibilities directly connected to the rock fabric heterogeneities (ductile-to-brittle deformation localization, metamorphism/metasomatism, and fluid flux) that are representative of the tectonic environments. The diagram suggests that $A_{\mathrm{H}}$ increases in ophiolites where a larger variety of deformation structures and associated metamorphic mineralisation can be expected due to the progressive superimposition of chronologically distinct tectono-metamorphic events.

(iv) the fluid flux (ff) experienced during the geological history of the rock. Such a relationship is here expressed as:

$A_{\mathrm{H}}=\mathrm{cd} \cdot \mathrm{sp} \cdot \mathrm{pd} \cdot \mathrm{ff}$.

Equation (8) is a parameterisation of the asbestos hazard in function of the main geological processes that are at the origin of the rock fabric heterogeneities in ophiolites, and Fig. 7 represents the probability of asbestos occurrence in qualitative terms (i.e. low to high probabilities) as a function of the tectonic/geodynamic environment. According to the literature on asbestos occurrence and hazard (see references in Table 1), $A_{\mathrm{H}}$ can be expressed as a spectrum of geological possibilities that are influenced by superimposition of chronologically distinct tectonic events (from sea-floor to orogenic), interconnection between different deformation patterns (ductile to brittle), multistage dynamic metamorphism/metasomatism, and polycyclic fluid/rock interaction. In processes involved in sea-floor exposure, localized rock deformation along lithospheric detachment and metasomatic fluid accomplish for decompression and cooling providing conditions for nucleation of chrysotile and low-T amphiboles (actinolite) within ductile-to-brittle deformation structures (e.g. Hoogerduijn Strating and Vissers, 1994; Vissers et al., 1995). On the other hand, a less pervasive deformation is expected for ophiolites adiabatically exhumed at mid- ridge spreading setting, where large volumes of these rocks preserve their original fabric (Müntener and Piccardo, 2003). In processes concerning orogenic events, a large variety of (polyphase) deformation structures and associated metamorphic mineralisation can be considered in ophiolites experiencing the complete subduction-exhumation orogenic cycle (Scambelluri et al., 1995; Hermann et al., 2000; Barnes et al., 2004; Li et al., 2004). In this case, due to the progressive superimposition of chronologically distinct tectonometamorphic events, the interaction between progressive deformation (from ductile to brittle conditions), decompression/cooling, and fluid circulation enhances the structural permeability in the rock mass (e.g. Oliver, 1996). Defining occurrence and possible interaction between rock fabrics derived from different geological processes is fundamental to assess the distribution of the asbestos-bearing localised zones.

\section{The geological multidisciplinary approach}

In order to fix the mode and types of asbestos occurrence in ophiolites, we propose that geological-structural field work aimed at defining the deformation fabrics of the host rock should be the prerequisite of a multidisciplinary geological research program that includes mineralogical, petrological, 


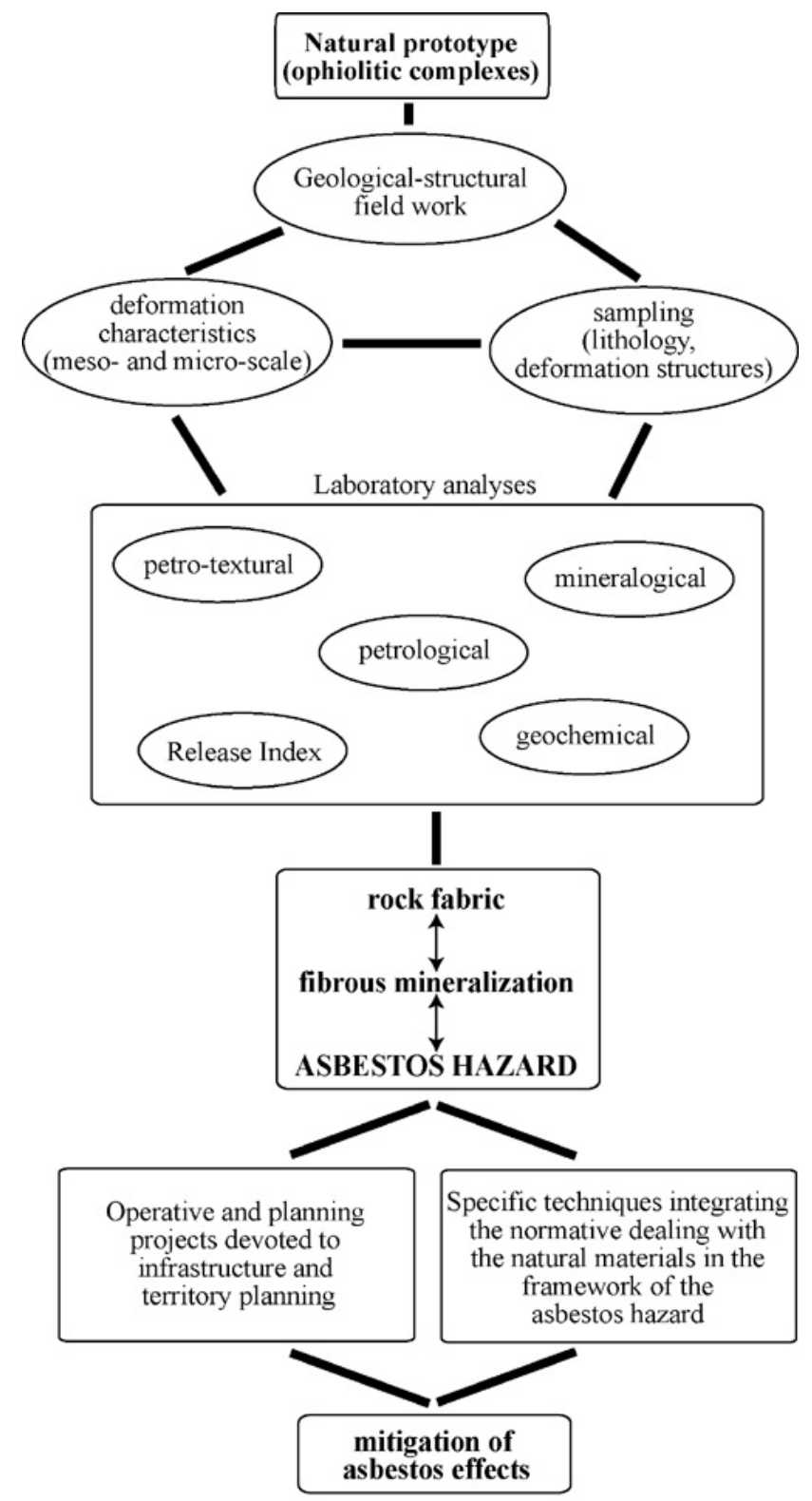

Fig. 8. Flowchart of the proposed multidisciplinary approach correlating the geological properties of the ophiolitic rocks to the asbestos hazard.

and geochemical analyses. The flowchart shown in Fig. 8 delineates such an approach, which is detailed below.

The geological-structural survey carried out at the proper scale should focus on the geometry (i.e. spatial distribution, width, and frequency), character (brittle vs. ductile), and attitude of those structures in which fibrous mineralisation is visible at the naked eye. The systematic sampling of different lithologies, deformation structures, and related mineralisation are critical to a series of laboratory analyses to identify:
1. the petrographic-structural characteristics. Meso- and micro-scale investigations aided by back-scattered electron images acquired at the scanning electron microscope (SEM) scale will be addressed to define relations between different generations of mineral types and geometry and texture of the main deformation structures. For the identification, description, and quantitative determination of common fibrous minerals, both traditional techniques (optical microscopy, X-ray powder diffraction, and infrared spectroscopy) and recent techniques ( $\mu$-Raman spectroscopy) should be used. Optical microscopy, together with SEM and transmission electron microscope observations, allows characterising the petro-textural and morphological features of the fibres. Diffraction and infrared spectroscopy provide determination on the chemistry of the fibrous mineral. The $\mu$-Raman spectroscopy helps to quickly identify fibrous minerals, especially those of the serpentine group, directly on the rock chip (Rinaudo et al., 2003; Groppo et al., 2006). The goal is the assessment of the linkage between rock fabrics and types of fibrous mineralisation;

2. the thermobarometric environmental conditions for asbestos crystallization. Based on quantitative chemical analyses of equilibrium mineral assemblages, $P-T$ estimates obtained from both inverse and forward petrological modelling techniques (Powell and Holland, 2008) are compared in order to define the $P-T$ trajectory followed by the host rock and recognize the potential $P-T$ regimes compatible with asbestos crystallization;

3. the geochemistry of the fluid/rock interaction processes leading to rock alteration and asbestos growth in ophiolites. A whole-rock geochemical balance (major and trace elements) from the unaltered to the altered rock mass will be performed to derive the volume and chemistry of the circulating fluids. Fluid inclusions analyses integrated with stable isotopes systematics are used to reconstruct the linkage between deformation history and the paleo-fluid circulation system. These investigations will determine the source, the volume, and the physical-chemical parameters of the fluids accompanying fibrous mineralisation in deformation structures;

4. the textural-morphological aspect of fibres investigated at optical microscopy and through SEM analyses;

5. the degree of free asbestos fibre (referred as Release Index by the Italian Ministerial Decree no. 178, 14 May 1996) that can be produced by application of external stresses on the rock mass (crushing, milling; Bellopede et al., 2009). The aim is to link the geological properties of the rock sample with the type and quantity of particles that can be inhaled and thus considered dangerous to human health. The use of experimental apparatus to simulate the effects of crushing and areal dispersion of 
the rock fragments/fibres (e.g. Belardi et al., 2008) may provide a standardised and robust database.

The integration and synthesis of the various results should permit establishing correlations existing between (i) the development of deformation structures, the alteration mineralogy, and growth of asbestos in ophiolites; (ii) intrinsic geological properties of the rock mass (mineralogical composition, texture, mechanical properties); and (iii) the characteristics (in terms of shape, dimension, and quantity) of the air-dispersed particles generated by the different physicalmechanical solicitations.

The proposed multidisciplinary approach can provide the basis to propose a predictive protocol finalised to the mitigation of effects due to asbestos contamination in environments where asbestos still constitutes a problem. These environments can correspond to engineering operativities of extraction, transport, and storage of ophiolitic rocks devoted to infrastructures or territory planning (e.g. Rohl et al., 1977; Ross and Nolan, 2003; Bandli and Gunter, 2006; Giacomini et al., 2010; Vignaroli et al., 2010). Our approach aims to propose specific techniques supporting regulatory agencies dealing with the natural materials in the framework of the asbestos hazard that are currently based on morphological factors (fibre length/width ratio) and chemical compositions. We are confident that national and international organizations concerned with the environmental impact due to asbestos exposure (Kazan-Allen, 2005; Lee et al., 2008) will consider such geological studies as a baseline to improve mitigation effects and to help minimize the risk of asbestos exposure to the general population.

\section{Conclusions}

Our proposal aims to be placed at the source of the asbestos topic (see flowchart in Fig. 1). As asbestos naturally occurs in ophiolites, we suggest relating the geological properties of ophiolite suites with the asbestos hazard $\left(A_{\mathrm{H}}\right)$ in terms of rock fabric heterogeneities created in response to the different tectonic/geodynamic settings. Ophiolites in orogenic settings (recording oceanic formation at spreading centres to oceanic destruction at convergent margins) are expected to gain rock fabric systematics particularly prominent for the nucleation and growth of fibrous minerals, due to the feedback between cooling/decompression history (cd), secondary permeability (sp), polyphase deformation (pd), and fluid flux (ff). This correlation should be considered as a first step to outline the structural-metamorphic control on growth of asbestos in ophiolites. Understanding that fibrous mineral occurrence in natural prototype is a record of the structuralmetamorphic history helps to reconstruct an analytical and methodological procedure for investigation of the rock fabric aimed at evaluating the asbestos hazard. Our synthesis implies that the geological-structural context of a particular geological site defines a first-order aspect to be taken into consideration by asbestos regulatory agencies, especially in connection with habitual engineering operations of extraction, transport, and storage of ophiolitic rocks.

Acknowledgements. This paper benefited from the advice and contributions in the field by C. Faccenna, M. Malusà, V. Olivetti, R. Polino, G. Spagnolo, and G. Urru. Advice from F. Tecce and T. Theye are also acknowledged. We are grateful to the reviewers (M. E. Gunter and B. S. Van Gosen) for significantly improving the quality of the manuscript and to the Editor (F. Guzzetti) for handling the manuscript. This work is in memory of R. Funiciello, who first introduced us into this research project.

Edited by: F. Guzzetti

Reviewed by: M. Gunter and B. S. Van Gosen

\section{References}

Agard, P., Yamato, P., Jolivet, L., and Burov, E.: Exhumation of oceanic blueschists and eclogites in subduction zones: timing and mechanisms, Earth-Sci. Rev., 92, 53-79, 2009.

Andreani, M., Baronnet, A., Boullier, A. M., and Gratier, J. P.: A microstructural study of a "crack-seal" type serpentine vein using SEM and TEM techniques, Eur. J. Mineral., 16, 585-595, 2004.

Andreani, M., Boullier, A. M., and Gratier, J. P.: Development of schistosity by dissolution-crystallization in a Californian serpentinite gouge, J. Struct. Geol., 27, 2256-2267, 2005.

Andreani, M., Mével, C., Boullier, A.-M., and Escartin, J.: Dynamic control on serpentine crystallization in veins: constraints on hydration processes in oceanic peridotites, Geochemistry-Geophysics-Geosystems, 8, Q02012, doi:Q02012/2006GC001373, 2007.

Atkinson, B. K.: Introduction to fracture mechanics and its geophysical applications, in: Fracture mechanics of rock, edited by: Atkinson, B. K., Academic Press, London, 1-26, 1987.

Auzende, A.-L., Guillot, S., Devouard, B., and Baronnet, A.: Serpentinites in an Alpine convergent setting: effects of metamorphic grade and deformation on microstructures, European Journal of Mineralogy, 18, 21-33, 2006.

Bandli, B. R. and Gunter, M. E.: A review of scientific literature examining the mining history, geology, mineralogy, and amphibole asbestos health effects of the Rainy Creek Igneous Complex, Libby, Montana, USA, Inhalation Toxicology, 18, 949-962, 2006.

Barker, S. L. L., Cox, S. F., Eggins, S. M., and Gagan, M. K.: Microchemical evidence for episodic growth of antitaxial veins during fracture-controlled fluid flow, Earth Planet. Sci. Lett., 250, 331-344, 2006.

Barnes, J. D., Selverstone, J., and Sharp, Z. D.: Interactions between serpentinite devolatilization, metasomatism and strike-slip strain localization during deep-crustal shearing in the Eastern Alps, J. Metamorph. Geol., 22, 283-300, 2004.

Bebout, G. E.: Metamorphic chemical geodynamics of subduction zones, Earth Planet. Sci. Lett., 260, 373-393, 2007.

Belardi, G., Spaziani, E., and Passeri, L.: La prova di automacinazione secondo il D.M. 14 maggio 1996 : analisi degli effetti prodotti dalle principali variabili operative sulla curva granulometrica ottenuta a seguito del test, Geoingegneria Ambientale e Mineraria, GEAM, Anno XLV, n. II, 5-21, 2008. 
Bellopede, R., Clerici, C., Marini, P., and Zanetti, G.: Rocks with Asbestos: Risk Evaluation by Means of an Abrasion Test, Am. J. Environm. Sci., 5, 500-506, 2009.

Bellot, J. P.: Natural deformation related to serpentinisation of an ultramafic inclusion within a continental shear zone: The key role of fluids, Tectonophysics, 449, 133-144, 2008.

Belluso, E., Bellis, D., Bruni, B. M., Capella, S., Coverlizza, S., Ferraris, G., Fornero, E., Paoletti, L., and Rinaudo, C.: Studio preliminare sulla valutazione indiretta delle fibre inorganiche respirabili aerodisperse in Valle di Susa (Piemonte - Alpi Occidentali), Rend. Soc. Geol. It., 3, 41-45, 2006.

Boschi, C., Früh-Green, G. L., and Escartín, J.: Occurrence and significance of serpentinite-hosted, talc- and amphibole-rich fault rocks in modern oceanic settings and ophiolite complexes: an overview, Ofioliti, 31, 129-140, 2006.

Bucher, K. and Frey, M.: Petrogenesis of Metamorphic Rocks, Springer-Verlag,Heidelberg, 319 p, 2002.

Burilkov, T. and Michailova, L.: Asbestos content of the soil and endemic pleural asbestosis, Environm. Res., 3, 443-451, 1970.

Caine, J. S., Evans, J. P., and Forster, C. B.: Fault zone architecture and permeability structure, Geology, 24, 1025-1028, 1996.

Cattaneo, A., Cavallo, D. M., and Foà, V.: Patologia umana conseguente all'inalazione di fibre di asbesto, Rend. Soc. Geol. It., 3, 37-40, 2006.

Cawood, P. A., Kröner, A., Collins, W. J., Kusky, T. M., Mooney, W. D., Windley, B. F.: Accretionary orogens through Earth history, in: Earth Accretionary Systems in Space and Time, edited by: Cawood, P. A. and Kröner, A., Geolog. Soc., London, Sp. Publ., 318, 1-36, 2009.

Cloos, M. and Shreve, R. L.: Subduction-channel model of prism accretion, melange formation, sediment subduction, and subduction erosion at convergent plate margins: 1 . Background and description, Pure Ap. Geoph., 128, 455-500, 1988.

Coleman, R. G.: Plate tectonic emplacement of upper mantle peridotites along continental edges, J. Geophys. Res., 76, 12121222, 1971.

Coleman, R. G.: Ophiolites: ancient oceanic lithosphere?, Berlin: Springer-Verlag, 229 pp, 1977.

Coleman, R. G.: Tectonic Setting for Ophiolite Obduction in Oman, J. Geophys. Res., 86, 2497-2508, 1981.

Compagnoni, R. and Groppo, C.: Gli amianti in Val di Susa e le rocce che li contengono, Rend. Soc. Geol. It., 3, 21-28, 2006.

Compagnoni, R., Ferraris, G., and Fiora, L.: Balangeroite, a new fibrous silicate related to gageite from Balangero, Italy, Am. Mineral., 6, 214-219, 1983.

Compagnoni, R., Ferraris, G., and Mellini, M.: Carlosturanite, a new asbestiform rock-forming silicate from Val Varaita, Italy, Am. Mineral., 70, 767-772, 1985.

Cox, S. F. and Etheridge, M. A.: Coupled grain-scale dilatancy and mass transfer during deformation at high fluid pressures: examples from Mount Lyell, Tasmania, J. Struct. Geol., 11, 147-162, 1989.

Dale, J., Powell, R., White, R. W., Elmer, F. L., and Holland, T. J. B.: A thermodynamic model for $\mathrm{Ca}-\mathrm{Na}$ clinoamphiboles in $\mathrm{Na} 2 \mathrm{O}-\mathrm{CaO}-\mathrm{FeO}-\mathrm{MgO}-\mathrm{Al} 2 \mathrm{O} 3-\mathrm{SiO} 2-\mathrm{H} 2 \mathrm{O}-\mathrm{O}$ for petrological calculations, J. Metamorph. Geol., 23, 771-791, 2005.

de Grisogono, F. M. and Mottana, A.: The impact of malignant pleural mesothelioma throughout Italy in the years 1995-2002: a geo-referenced study relating death rate to population distribu- tion, Rend. Fis. Acc. Lincei, 20, 117-137, 2009.

Dewey, J. F. and Bird, J. M.: Mountain Belts and the New Global Tectonics, J. Geoph. Res., 75, 2625-2647, 1970.

Dilek, Y. and Robinson, P. T. (Eds.): Ophiolites in Earth History, Geol. Soc., London, Sp. Publ., 218 p., 2003.

Doll, R.: Mortality from lung cancer in asbestos workers, British Journal of Industrial Medicine, 12, 81-86, 1955.

Emmanouil, K., Kalliopi, A., Dimitrios, K., and Evangelos, G.: Asbestos pollution in an inactive mine: Determination of asbestos fibers in the deposit tailings and water, J. Haz. Mat., 167, 10801088, 2009.

Etheridge, M. A., Wall, V. J., Cox, S. F., and Vernon, R. H.: High fluid pressures during regional metamorphism and deformation: implication for mass transport and deformation mechanism, J. Geophys. Res., 89, 4344-4358, 1984.

Evans, B. W.: Metamorphism of alpine peridotite and serpentinite, Ann. Rev. Earth Planet. Sci., 5, 397-447, 1977.

Evans, B. W.: Phase relations of epidote-blueschists, Lithos, 25, 3-23, 1990.

Evans, B. W.: The Serpentinite Multisystem Revisited: Chrysotile Is Metastable, Int. Geol. Rev., 46, 479-506, 2004.

Ferry, J. M.: A historical review of metamorphic fluid flow, J. Geophys. Res., 99, 15487-15498, 1994.

Gabrielse, H.: The genesis of chrysotile asbestos in the Cassiar Asbestos deposit, northern British Columbia, Econ. Geol., 55, 327337, 1960.

Giacomini, F., Boerio, V., Polattini, S., Tiepolo, M., Tribuzio, R., and Zanetti, A.: Evaluating asbestos fibre concentration in metaophiolites: a case study from the Voltri Massif and SestriVoltaggio Zone (Liguria, NW Italy), Environ. Earth Sci., 61, 1621-1639, doi:10.1007/s12665-010-0475-9, 2010.

Gianfagna, A., Ballirano, P., Bellatreccia, F., Bruni, B., Paoletti, L., and Oberti, R.: Characterization of amphibole fibres linked to mesothelioma in the area of Biancavilla, Eastern Sicily, Italy, Mineral. Magaz., 67, 1221-1229, 2003.

Gibbons, W.: The Exploitation and Environmental Legacy of Amphibole Asbestos: A Late 20th Century Overview, Environ. Geochem. Health, 20, 213-230, 1998.

Gibbons, W.: Amphibole asbestos in Africa and Australia: geology, health hazard and mining legacy. Geol. Soc., London, 157, 851858, 2000.

Giguère, E., Hébert, R., Beaudoin, G., Bedard, J. H., and Berclaz, A.: Hydrothermal circulation and metamorphism in crustal gabbroic rocks of the Bay of Islands ophiolite complex, Newfoundland, Canada: evidence from mineral and oxygen isotope geochemistry, in: Ophiolites in Earth History, edited by: Dilek, Y. and Robinson, P. T., Geol. Soc., London, Sp. Publ., 218, 369400, 2003.

Gray, D. R. and Gregory, R. T.: Ophiolite obduction and the Samail Ophiolite: the behaviour of the underlying margin, in: Ophiolites in Earth History, edited by: Dilek, Y. and Robinson, P. T., Geol. Soc., London, Sp. Publ., 218, 449-465, 2003.

Groppo, C. and Compagnoni, R.: Ubiquitous fibrous antigorite veins from the Lanzo Ultramafic Massif, Internal Western Alps (Italy): characterisation and genetic conditions, Per. Mineral., 76, 169-181, 2007.

Groppo, C., Rinaudo, C., Cairo, S., Gastaldi, D., and Compagnoni, R.: Micro-Raman spectroscopy for a quick and reliable identification of serpentinite minerals from ultramafics, Europ. J. Min- 
eral., 18, 319-329, 2006.

Guillot, S., Hattori, K., Agard, P., Schwartz, S., and Vidal, O.: Exhumation processes in oceanic and continental subduction contexts: a review, in: Subduction zone geodynamics, edited by: Lallemand, S. and Funiciello, F., Springer-Verlag Berlin Heidelberg, 175-205, doi:10.1007/978-3-540-87974-9, 2009.

Gunter, M. E.: Defining Asbestos: Differences between the Built and Natural Environments, CHIMIA, 64, 747-752, 2010.

Gunter, M. E., Belluso, E., and Mottana, A.: Amphiboles: environmental and health concerns, Rev. Mineral. Geochem., 67, 453516, 2007.

Hacker, B., Peacock, S., Abers, G. A., and Holloway, S. D.: Subduction factory 2. Are intermediate-depth earthquakes in subducting slabs linked tometamorphic dehydration reactions?, J. Geophys. Res., 108, 2030, doi:10.1029/2001JB001129, 2003.

Hardy, R. J., Highsmith, V. R., Costa, D. L., and Krewert, J. A.: Indoor asbestos concentrations associated with the use of asbestoscontaminated tap water in portable home humidifiers, Environ. Sci. Technol., 26, 680-689, 1992.

Hendrickx, M.: Naturally occurring asbestos in eastern Australia: a review of geological occurrence, disturbance and mesothelioma risk, Environ. Geol., 57, 909-926, 2009.

Hermann, J. and Müntener, O.: Exhumation-related structures in the Malenco-Margna system: implications for paleogeography and its consequence for rifting and Alpine tectonics, Schweiz, Mineral. Petrogr. Mitt., 76, 501-520, 1996.

Hermann, J., Müntener, O., and Scambelluri, M.: The importance of serpentinite mylonites for subduction and exhumation of oceanic crust, Tectonophysics, 327, 225-238, 2000.

Hirauchi, K. I. and Yamaguchi, H.: Unique deformation processes involving the recrystallization of chrysotile within serpentinite: implications for aseismic slip events within subduction zones, Terra Nova, 19, 454-461, 2007.

Hirose, T., Bystricky, M., Kunze, K., and Stünitz, H.: Semi-brittle flow during dehydration of lizardite-chrysotile serpentinite deformed in torsion: Implications for the rheology of oceanic lithosphere, Earth Planet. Sci. Lett., 249, 484-493, 2006.

Hoogerduijn Strating, E. H. and Vissers, R. L. M.: Structures in natural serpentinite gouges, J. Struct. Geol., 16, 1205-1215, 1994.

Hughes, J. M. and Weill, H.: Asbestosis as a precursor of asbestos related lung cancer: results of a prospective mortality study, British Journal of Industrial Medicine, 48, 229-233, 1991.

IARC (International Agency for Research on Cancer): Monographs on the Evaluation of Carcinogenic Risks to Humans. Overall Evaluations of Carcinogenicity: An Updating of IARC Monographs. Volume 42, Supplement 7, 1987.

Italian Ministerial Decree no. 178: Normative e metodologie tecniche per gli interventi di bonifica, ivi compresi quelli per rendere innocuo l'amianto, previsti dall'art. 5, comma 1, lettera f), della legge 27 marzo 1992, n. 257, recante: "Norme relative alla cessazione dell'impiego dell'amianto", published in the Official Journal of the Italian Republic no. 251 of 25 October 1996, Ordinary Supplement, 14 May 1996.

Jolivet, L., Faccenna, C., Goffé, B., Burov, E., and Agard, P.: Subduction tectonics and exhumation of High-Pressure metamorphic rocks in the Mediterranean orogens, Am. J. Sci., 303, 353-409, 2003.

Karkanas, P.: The slip-fiber chrysotile asbestos deposit in the Zidani area, northern Greece, Ore Geology Reviews, 10, 19-29, 1995.
Kazan-Allen, L.: Asbestos and mesothelioma: Worldwide trends, Lung Cancer, 49S1, S3-S8, 2005.

Kerrich, R.: Fluid Infiltration into Fault Zones: Chemical, Isotopic, and Mechanical Effects, Pure Ap. Geoph., 124, 225-268, 1986.

Kyser, T. K., O'Hanley, D. S., and Wicks, F. J.: The origin of fluids associated with serpentinization processes: evidence from stableisotope compositions, Canad. Mineral., 37, 223-237, 1999.

Lange, J. H., Lange, P. R., Reinhardt, T. K., and Thomulkat, K. W.: A study of personal and area airborne asbestos concentrations during asbestos abatement: a statistical evaluation of fibre concentration data, The Annals of Occupational Hygiene, 40, 449466, 1996.

Lee, R. J., Strohmeier, B. R., Bunker, K. L., and Van Orden, D. R.: Naturally occurring asbestos - A recurring public policy challenge, J. Hazardous Materials, 153, 1-21, 2008.

Li, X. P., Rahn, M., and Bucher, K.: Serpentinites of the ZermattSaas ophiolite complex and their texture evolution, J. Metamorph. Geol., 22, 159-177, 2004.

Marquer, D. and Burkhard, M.: Fluid circulation, progressive deformation and mass-transfer processes in the upper crust: the example of basement-cover relationships in the External Crystalline Massifs, Switzerland, J. Struct. Geol., 14, 1047-1057, 1992.

McKenzie, D. P. and Bickle, M. J.: The volume and composition of melt generated by extension of the lithosphere, J. Petrol., 29, 625-679, 1988.

Meeker, G. P., Bern, A. M., Brownfield, I. K., Lowers, H. A., Sutley, S. J., Hoefen, T. M., and Vance, J. S.: The Composition and Morphology of Amphiboles from the Rainy Creek Complex, near Libby, Montana, Am. Mineral., 88, 1955-1969, 2003.

Metintas, S., Metintas, M., Ucgun, I., and Oner, U.: Malignant mesothelioma due to environmental exposure to asbestos, Chest, 122, 2224-2229, 2002.

Mével, C.: Serpentinization of abyssal peridotites at mid-ocean ridges, C. R. Geoscience, 335, 825-852, 2003.

Moores, E. M.: Origin and emplacement of ophiolites, Rev. Geophys. Space Phys., 20, 737-760, 1982.

Mossman, B. T., Bignon, J., Corn, M., Seaton, A., and Gee, J. B. L.: Asbestos: scientific developments and implications for public policy, Science, 247, 294-301, 1990.

Müntener, O. and Piccardo, G. B.: Melt migration in ophiolitic peridotites: the message from Alpine-Apennine peridotites and implications for embryonic ocean basins, in: Ophiolites in Earth History, edited by: Dilek, Y. and Robinson, P. T., Geol. Soc., London, Sp. Publ., 218, 69-89, 2003.

Norrell, G. T., Teixell, A., and Harper, G. D.: Microstructure of serpentinite mylonites from the Josephine ophiolite and serpentinization in retrogressive shear zones, California, Geol. Soc. Am. Bull., 101, 673-682, 1989.

Nuriel, P., Katzir, Y., Abelson, M., Valley, J. W., Matthews, A., Spicuzza, M. J., and Ayalon, A.: Fault-related oceanic serpentinization in the Troodos ophiolite, Cyprus: implications for a fossil oceanic core complex, Earth Planet. Sci. Lett., 282, 34-46, 2009.

O'Hanley, D. S.: Fault-related phenomena associated with hydration and serpentine recrystallization during serpentinization, The Canadian Mineralogist, 29, 21-35, 1991.

Oliver, N. H. S.: Review and classification of structural controls on fluid flow during regional metamorphism, J. Metamorph. Geol., 14, 477-492, 1996. 
Otsuki, M. and Banno, S.: Prograde and retrograde metamorphism of hematite-bearing basic schists in the Sanbagawa belt in central Shikoku, J. Metamorph. Geol., 8, 425-439, 1990.

Parra, T., Vidal, O., and Jolivet, L.: Relation between the intensity of deformation and retrogression in blueschist metapelites of Tinos Island (Greece) evidenced by chlorite-mica local equilibria, Lithos, 63, 41-66, 2000.

Passchier, C. W. and Trouw, R. A. J.: Microtectonics. Berlin: Springer-Verlag, 371 pp, 2005.

Peacock, S. M.: Thermal and Petrologic structure of subduction zones, in: Subduction: Top to Bottom, edited by: Bebout, G. E., Scholl, D. W., Kirby, S. H., and Platt, J. P., Geophysical Monograph Ser. American Geophysical Union,Washington, D.C., pp. 119-133, 1996.

Phillips, F. C.: The serpentines and associated rocks and minerals of the Shetland Islands, Q. J. Geol. Soc., 83, 622-652, doi:10.1144/GSL.JGS.1927.083.01-05.26, 1927.

Piccardo, G. B., Rampone, E., and Scambelluri, M.: The Alpine evolution of the Erro-Tobbio peridotites (Voltri Massif - Ligurian Alps): some field and petrographic constraints, Ofioliti, 13, 169174, 1988.

Platt, J. P.: Dynamics of orogenic wedges and the uplift of highpressure metamorphic rocks, Geol. Soc. Am. Bull., 27, 10371053, 1986.

Platt, J. P.: Exhumation of high-pressure rocks: a review of concepts and processes, Terra Nova, 5, 119-133, 1993.

Powell, R. and Holland, T. J. B.: On thermobarometry, J. Metamorph. Geol., 26, 155-180, 2008.

Reinen, L. A.: Seismic and aseismic slip indicators in serpentinite gouge, Geology, 28, 135-138, 2000.

Rey, F., Boutin, C., Viallat, J. R., Steinbauer, J., Alessandroni, P., Jutisz, P., Di Giambattista, D., Billon-Galland, M. A., Hereng, P., Dumortier, P., and De Vuyst, P.: Environmental asbestotic pleural plaques in northeast Corsica: Correlation with airborne and pleural mineralogic analysis, Environ. Health Perspect., 102, 251-252, 1994.

Rinaudo, C., Gastaldi, D., and Belluso, E.: Characterization of chrysotile, antigorite and lizardite by FT-Raman spectroscopy, Can. Mineral., 41, 883-890, 2003.

Rohl, A. N., Langer, A. M., and Selikoff, I. J.: Environmental asbestos pollution related to use of quarried serpentine quarries, Science, 196, 1319-1322, 1977.

Ross, M. and Nolan, R. P.: History of asbestos discovery and use and asbestos-related disease in context with the occurrence of asbestos within ophiolite complexes, Geol. Soc. Am., Sp. paper, 373, 447-470, 2003.

Rossetti, F., Faccenna, C., Goffé, B., Monié, P., Argentieri, A., Funiciello, R., and Mattei, M.: Alpine structural and metamorphic signature of the Sila PiccolaMassif nappe stack (Calabria, Italy): Insights for the tectonic evolution of the Calabrian Arc, Tectonics, 20, 112-133, 2001.

Scambelluri, M., Hoogerduijn Strating, E. H., Piccardo, G. B., Vissers, R. L. M., and Rampone, E.: Alpine olivine- and titanian clinohumite-bearing assemblages in the Erro-Tobbio peridotite (Voltri Massif, NW Italy), J. Metamorph. Geol., 9, 79-91, 1991.

Scambelluri, M., Müntener, O., Hermann, J., Piccardo, G. B., and Trommsdorff, V.: Subduction of water into the mantle: history of an Alpine peridotite, Geology, 23, 459-462, 1995.

Scambelluri, M. and Philippot, P.: Deep fluids in subduction zones,
Lithos, 55, 213-227, 2001.

Schmidt, M. W. and Poli, S.: Generation of mobile components during subduction of oceanic crust, Treat. Geochem., 3, 567591, 2003.

Schreier, H.: Asbestos in the natural environment, Elsevier, Studies in Environmental Science, 37, 158 pp, 1989.

Searle, M. P., Warren, C. J., Waters, D. J., and Parrish, R. R.: Subduction zone polarity in the Oman Mountains: implications for ophiolite emplacement, in: Ophiolites in Earth History, edited by: Dilek, Y. and Robinson, P. T., Geol. Soc., London, Sp. Publ., 218, 467-480, 2003.

Sebastien, P., Bignon, J., and Martin, M.: Indoor airborne asbestos pollution: from the ceiling and the floor, Science, 216, 1410 1413, 1982.

Spear, F. S.: Metamorphic Phase Equilibria and PressureTemperature-Time Paths, Washington, D.C.: Mineral. Soc. Am., 799 pp, 1993.

Strohmeier, B. R., Huntington, J. C., Bunker, K. L., Sanchez, M. S., Allison, K., and Lee, R. J.: What is asbestos and why is it important? Challenges of defining and characterizing asbestos, Int. Geol. Rev., 52, 801-872, 2010.

Sullivan, P. A.: Vermiculite, respiratory disease and asbestos exposure in Libby, Montana: update of a cohort mortality study, Environ. Health Persp., 115, 579-585, 2007.

Thompson, B. D., Gunter, M. E., and Wilson, M. A.: Amphibole asbestos soil contamination in the USA: A matter of definition, Am. Min., 96, 690-693, 2011.

Trommsdorff, V. and Evans, B. W.: Alpine metamorphism of peridotitic rocks. Schweiz, Mineral. Petrogr. Mitt., 54, 333-352, 1974.

Van Gosen, B. S.: The geology of asbestos in the United States and its practical applications, Environ. Eng. Geosci., 13, 55-68, 2007.

Vignaroli, G., Rossetti, F., Belardi, G., and Billi, A.: Studio geologico-strutturale per l'ottimizzazione della coltivazione di rocce ofiolitiche: il caso della cava "Tana dei Banditi" in località Carpenara (Genova), Geoingegneria Ambientale e Mineraria (GEAM), 130, 5-14, 2010.

Vissers, R. L. M., Drury, M. R., Hoogerduijn Strating, E. H., Spiers, C. J., and van der Wal, D.: Mantle shear zones and their effect on lithosphere strength during continental breakup, Tectonophysics, 249, 155-171, 1995.

Wagner, J. C.: The discovery of the association between blue asbestos and mesotheliomas and the aftermath. British Journal of Industrial Medicine, 48, 399-403, 1991.

Whitmarsh, R. B., Manatschal, G., and Minshull, T. A.: Evolution of magma-poor continental margins from rifting to seafloor spreading, Nature, 413, 150-154, 2001.

Wicks, F. J. and Wittaker, E. J. W.: Serpentinite textures and serpentinization, Can. Mineral., 15, 459-488, 1977.

World Health Organization: Asbestos and other natural mineral fibres, Environmental Health Criteria, No. 53, Geneva, 1986.

Wunder, B., Wirth, R., and Gottschalk, M.: Antigorite: Pressure and temperature dependence of polysomatism and water content, Eur. J. Mineral., 13, 485-495, 2001.

Zakrzewska, A. M., Capone, P. P., Iannò, A., Tarzia, V., Campopiano, A., Villella, E., and Giardino, R.: Calabrian ophiolites: dispersion of airborne asbestos fibers during mining and milling operations, Per. Mineral., 72, 27-34, 2008. 